DIGITAL COMMONS

@ UNIVERSITY OF SOUTH FLORIDA

\section{ABO: Interactive Journal for Women in the Arts, 1640-1830}

\title{
Dangerous Women, Libertine Epicures, and the Rise of Sensibility, 1670-1730, by Laura Linker
}

Courtney Beggs
Bridgewater State University, courtney.beggs@bridgew.edu

Follow this and additional works at: https://digitalcommons.usf.edu/abo

Part of the Dramatic Literature, Criticism and Theory Commons, Educational Methods Commons, Feminist, Gender, and Sexuality Studies Commons, and the Literature in English, British Isles Commons

\section{Recommended Citation}

Beggs, Courtney (2013) "Dangerous Women, Libertine Epicures, and the Rise of Sensibility, 1670-1730, by Laura Linker," ABO: Interactive Journal for Women in the Arts, 1640-1830: Vol.3: Iss.1, Article 7. http://dx.doi.org/10.5038/2157-7129.3.1.7

Available at: https://digitalcommons.usf.edu/abo/vol3/iss1/7

This Reviews is brought to you for free and open access by Digital Commons @ University of South Florida. It has been accepted for inclusion in ABO: Interactive Journal for Women in the Arts, 1640-1830 by an authorized administrator of Digital Commons @ University of South Florida. For more information, please contact digitalcommons@usf.edu. 
Dangerous Women, Libertine Epicures, and the Rise of Sensibility, 1670-1730, by Laura Linker

\section{Keywords}

libertinism, sensibility, Aphra Behn, Catherine Trotter, Delariviere Manley, Amazons, Roxana, Lucretius

\section{Creative Commons License}

(c) $($ ) $\odot$

This work is licensed under a Creative Commons Attribution-No Derivative Works 3.0 License. 
Laura Linker. Dangerous Women, Libertine Epicures, and the Rise of Sensibility, 1670-1730. London: Ashgate, 2011. £55.00. 184 pp. ISBN: 9781409418115.

Reviewed by Courtney Beggs, Bridgewater State University.

In the first book-length study of the female libertine, Laura Linker traces the development of libertinism in the female characters that appear in works by John Dryden, Aphra Behn, Catharine Trotter, Delariviere Manley, and Daniel Defoe. As each type of female libertine is considered and defined, the author connects these characters, and often the writers themselves, to the philosophical foundations in which they may have originated. Thus, the work of Lucretius, Epicurus, Thomas Hobbes, and John Locke are explored as a way of framing the different types of female libertinism that characterized English writing during the Restoration and early eighteenth century. By studying several genres-drama, epistolary narratives, novella, and early fiction, Linker focuses on five representative types of the female libertine: Lady Lucretius, Lady Sensibility, the Humane Libertine, the Natural Libertine, and the Amazonian Libertine.

Beginning with Dryden, whose interest in Lucretius manifests itself not only in translations of his work in Sylvae: or the Second Part of the Poetical Miscellanies but also in many of his comedies, Marriage A-la-Mode in particular, Linker suggests that he establishes the earliest model for female libertinism during the Restoration: Lady Lucretius. Many of Dryden's works made direct reference to King Charles II's behavior. Connecting Dryden's references to the King and his court (especially his mistresses) with Lucretius's model for pleasure, Linker explores the ways that Marriage A-la-Mode critiques the libertine impulse to follow individualistic desire, generally through bodily means. Linker argues that Dryden's Lady Lucretius must endure and overcome suffering to achieve tranquility of the mind (22-23), thus distinguishing the concept of "katastematic" pleasure from the bodily pleasure experiences through sexual power and freedom. She usefully shows how Doralice and Melantha contrast with Palmyra and Amalthea and locates the play's conflict with the female characters, their language, sexual relationships, and attempts to challenge the court. While this reading of Dryden's play is relatively convincing, it would benefit from additional examples from contemporary writers in order to more solidly establish a pattern based on the Lucretian model.

Like Dryden, Aphra Behn occasionally wrote with Charles II's mistresses in mind (sometimes as models for her heroines and other times as dedicatees). In both her drama and short fiction, Behn experimented with female characters who are, at times, reminiscent of the violent and malicious rake figures of the Restoration. Other female characters, however, are also imbued with feeling and tenderness. It is their suffering, anguish, and psychological struggles that Linker suggests help to establish them as representative of Lady Sensibility, a female libertine who shares characteristics of traditional "libertinism and sensibilite" (59). Focusing on Behn's The Luckey Chance and The History of the Nun, Linker contends that Behn's Lady Sensibility, figured in heroines like Julia and Isabella, is motivated to write primarily by her "need to express and alleviate sorrow" (41). While the similarities between Isabella and Hortense Mancini, Duchess of Mazarin are useful to any analysis of The History of the Nun, there simply is not sufficient textual or historical evidence to equate the two as closely as Linker does. Unlike Isabella, Mazarin maintained a good deal of social and intellectual capital throughout the end of her life, as evidenced by her ability to secure for herself a residence in London until her death. 
The development of the female libertine as a character who uses the imaginative process of writing to resolve "the sexual tensions she feels" (80) is most successfully explored in Linker's chapter on Catharine Trotter. In both Olinda's Adventures and Love at a Loss, Trotter's heroines recall the Restoration libertine but remain focused on the "social consequences" of their actions. It is this awareness - of what marriage means for them, of how they will be judged by their community, of how they must act toward their lovers- that sets them apart from their more "malicious" (83) predecessors. Linker wisely recognizes that the ending of Love at a Loss remains ambiguous in terms of the marital happiness available to the couples, and it is this possibility of infidelity and "marital disillusionment" that grounds an understanding of the heroine, Miranda, as the Humane Libertine (90). The Humane Libertine was one who embodied "women's social and emotional distresses" (94), as well as their "erotic longings" (95) and sexual happiness. Trotter understood, however, the demands of her time, and her libertine heroines remained subject to the moral imperative that audiences expected.

The kind of restraint seen in the Humane Libertine is contrasted with what Linker argues is the defining characteristic of the Natural Libertine created by Delariviere Manley. In The Adventures of Rivella, Manley's heroine is set apart from "other female libertines who act out of spite" (98). According to Linker, Rivella is "a distinct figure interested in passion and overwhelming emotion" (99). This excess of feeling is shared with others through her stories, and through her physical and emotional struggles, she becomes a symbol of the persecuted female libertine. Linker contends that, what defines the Natural Libertine for Manley is the goodness of her heart, here seen as a "natural" force that motivates her actions. On one hand, this helps us to see how Manley is asking us to re-think what constitutes a "natural" woman. On the other hand, we must be careful that we are not simply perpetuating the natural/unnatural (or feminine/masculine) dichotomies. More attention to the ways we can avoid the latter would have strengthened this analysis of Manley's work.

Linker locates the next stage of the female libertine - the Amazonian Libertine-in Daniel Defoe's Roxana. Placing Defoe in the context of anti-Epicureanism in England during the mid1700s, she suggests that his concern with the ethical questions posed by both Lucretius and Hobbes influenced Defoe's creation of a female libertine who lacks the emotional or religious motivation to secure her salvation. For the first time, the female libertine is figured directly as a "Man-Woman," whose desire for freedom reveals that "she is an unnatural and unfeeling character with stereotypically masculine qualities" (123). While many critics have insisted that Roxana is an "exemplar of female independence," Linker makes a convincing case for reading Roxana as unable to form any "spiritual attachment to love as a life-affirming emotion that brings humans together" (128).

Though Linker's reading of Roxana's moral and emotional lethargy may be accurate, it is not entirely clear why the Amazon must serve as the model for this particular kind of libertinism. Linker wisely frames her consideration of the various spectacles that Roxana designs, observes, and participates in within the context provided by James Turner's foundational work on libertine culture during the eighteenth century. However, in claiming that the Amazonian Libertine is the "most dangerous figure of all" (138), Linker does not move beyond the argument that, because Roxana is "disruptive" to gender categories, she is a literal monstrosity devoid of virtue. Such a 
framework does not account for cultural and literary histories of Amazon women, and it perpetuates a gendered understanding of religious principles and motherhood that is problematic to feminist literary criticism.

Linker's conclusion offers a wonderful discussion of the differences between female libertines and coquettes, a distinction that would have been helpful to readers much earlier in the study. Ultimately, Linker's analysis provides a rich account of the development of the female libertine and will be a useful starting point for future scholarship on female libertinism. 